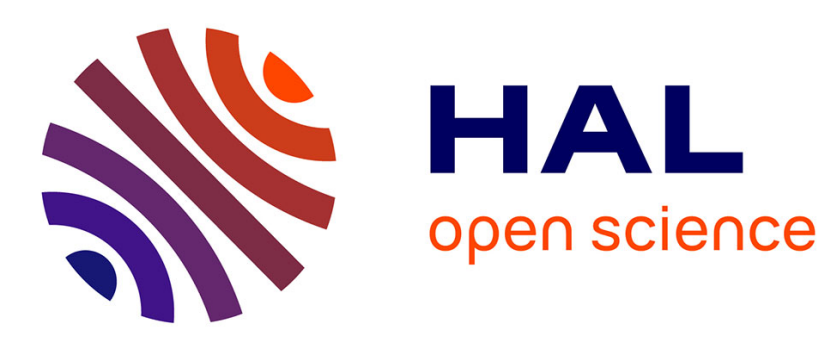

\title{
Migrant children's digital stories
}

Sonja de Leeuw, Ingegerd Rydin

\section{To cite this version:}

Sonja de Leeuw, Ingegerd Rydin. Migrant children's digital stories. European Journal of Cultural Studies, 2007, 10 (4), pp.447-464. 10.1177/1367549407081948 . hal-00571557

\section{HAL Id: hal-00571557 https://hal.science/hal-00571557}

Submitted on 1 Mar 2011

HAL is a multi-disciplinary open access archive for the deposit and dissemination of scientific research documents, whether they are published or not. The documents may come from teaching and research institutions in France or abroad, or from public or private research centers.
L'archive ouverte pluridisciplinaire HAL, est destinée au dépôt et à la diffusion de documents scientifiques de niveau recherche, publiés ou non, émanant des établissements d'enseignement et de recherche français ou étrangers, des laboratoires publics ou privés. 
Copyright (C) 2007 SAGE Publications Los Angeles, London, New Delhi and Singapore

Vol 1o(4) 447-464; 1367-5494 DOI: $10.1177 / 1367549407081948$ www.sagepublications.com

\section{Migrant children's digital stories}

Identity formation and selfrepresentation through media production

\section{Sonja de Leeuw \\ University of Utrecht}

\section{Ingegerd Rydin}

Halmstad University

ABSTRACT This article starts out from the European research project

Children in Communication about Migration (CHICAM). It addresses questions about intercultural communication via the internet and about media production as a vehicle for personal expression and identity

formation among excluded youth groups. The article starts out from a cultural theoretical perspective linked to an empirical analysis, which is based on a series of selected productions made by 12 to 14-year-old refugees. The productions represent various programme genres and formats. The use of visual language such as representational conventions are highlighted in order to find out how identities are (re)created in the process of media production. The article touches upon these productions as they reflect not only experiences in dealing with cultural tensions between the 'old' and the 'new' world, but also their views on their future life and on the conditions that they find crucial in developing themselves.

KEYWORDS Europe, intercultural communication, media production, migrant, new media, visual language, young people

Media are an increasingly important platform on which children express their social relationships with others and the institutions of society. As media become more user-friendly and accessible, they provide us with another way to study children's lives. We begin from the underlying assumption that children are active agents in making meaning in their lives and negotiating their identities through their social interactions, in the same way as adults. Even if children's lives are framed and structured by society and its major institutions, such as family and school, there is 
room for children to develop their own cultural spaces separate from the adult world.

The data that this article draws upon come from a European action research project based on six media clubs for refugee and migrant children (ages 10-14) in six European countries: Children in Communication about Migration (CHICAM; see for example, De Block et al. 2004). The countries involved were Germany, Greece, Italy, the Netherlands, Sweden and the United Kingdom. As a research project, CHICAM addressed three major aspects of structural change in contemporary European society: the increase in global migration, the uses of new communication technologies, and the specific needs of children. The project investigated how these children represent and express their experiences of migration to the different host countries. Its overall goal was to study how new media might enable children's perspectives to inform the development of European educational and cultural policies.

The purpose of this article is to see how the children's experiences of cultural identities could be traced in their media productions. It refers here to the extent to which they relate themselves to others in terms of, for example, religion, nationality and ethnicity. In the context of the project, looking at how children's heritage with regard to, for example, music, visual culture and storytelling is combined with, or fuses into, global and local youth culture, might be one way of answering the question.

Social and cultural theory emphasize that identity is a hybrid and dynamic concept, formed in the relationship and interaction between the individual and their social and cultural environment (Giddens, 1991; Hall, 1996b). Identity has different dimensions, of which ethnicity is particularly relevant in the context discussed here. Ethnic identity involves orientations towards a common descent, history and culture (such as religion, ritual practices and language), providing a source that people use in negotiating their identities. Hall distinguishes between the dominant notion of ethnicity as connected to nation and 'race', and a non-essentialist notion of ethnicity, recognizing

that we all speak from a particular place, out of a particular history, out of a particular experience, a particular culture without being contained by that position as ethnic artists or filmmakers. We are all in that sense, ethnically located and our ethnic identities are crucial to our subjective sense of who we are. (Hall, 1996a: 447)

Hall's reference to media production practices stems from his argument that identity construction is to be found only in representations, in narratives: 'Identities are therefore constituted within, not outside representation' (Hall, 1996b: 4). Consequently, the process of identity construction is active in both the perception and production of representations.

It has to be said that the relationship between media use and identity construction is almost entirely theoretically assumed (e.g. Alasuutari, 1999; 
Barker, 1997; Morley and Robins, 1995). The scarce empirical work within this field illustrates how media are indeed a strong socializing instrument in the lives of children in their early adolescence (e.g. Huntemann and Morgan, 2001). Gillespie's study on Southall Asian youth shows, on a more concrete level, how people shift across subject positions according to circumstances. Many youngsters are not only involved in shifting identifications, but in enacting a hybrid identity that draws on multiplying global sources (Gillespie, 2000[1995]).

As migration was central to the CHICAM project, Dayan's (1999) argument on the relationship between diaspora and media is relevant here. Diaspora is a contested term currently being theorized and debated. In general, it describes the migration and displacement of groups in their dislocation from the homeland, which maintain continuous links to the country of origin (e.g. Braziel and Mannur, 2005). Communities in diaspora, Dayan argues, increasingly form micro-public spheres, interacting with the macro-public sphere and providing spaces for minority groups to produce mediated conceptions of the self and the community, for example, in private media productions. In his view, the process of identity construction can be only partially analysed when focusing exclusively on public media. Particularistic media and private media also have to be included in the research. The project presented here focused particularly on offering a space for children to produce these private media forms, as the project addressed the children as individuals who were given a cultural and social space in which they could express themselves and explore the relationship between their individual position (as a teenager, as a migrant) and the social and cultural environment, thus speaking from a particular place, history, experience and culture. In the media club, they had to shift position from media consumers to media producers. In this respect, it is relevant to discuss this shift in relation to their basic reading skills, and how these skills were used in producing stories, images and shots.

In the media club, by making media productions, the children were offered the possibility of constructing (new) identities and continuities and redefining their notion of 'home'. This article will touch upon these productions, as they reflect not only their experiences in dealing with cultural tensions between the 'old' and the 'new' world, but also their views on their future life and the conditions that they find crucial in developing themselves. Furthermore, children today live in a highly mediasaturated society, and at a very early stage they become familiar with the codes and conventions of storytelling. Stimulating visual thinking may cause children to become sensitive to the non-verbal or visual potential of media. Exploring the possibilities of communication through images may have particular relevance when working with migrant children.

This article will focus on a small set of productions from the CHICAM project, which have been selected to provide examples of how selfrepresentational processes and identity construction come to the surface 
in various media genres. The selected productions present plots that deal with social and emotional relations between peers, with family members or with ties to the home country. They reflect on present moments of life, or on life as it was in the home country.

\section{Method}

\section{Participants}

The children came from very different countries and continents: Kosovo, Africa (Angola, Congo, Ethiopia, Morocco, Somalia), Latin America (Colombia, Ecuador, Peru) and Asia (Afghanistan, Iraq, Syria, Turkey). Most families arrived as refugees or asylum-seekers, others as immigrants under labour migration laws. Some children lived with a complete nuclear family in one house, with a mother, father, brothers and sisters. Others lived with separated families, missing a father or mother and sometimes both, and still more had dead or missing relatives. Most families had relatives in third countries with whom they were in contact. Thus, the children had generally experienced some degree of discontinuity related to their migratory situation.

The experience of living in diaspora had marked each family differently. It goes without saying that the experience of discontinuity had a great influence on the children's lives. For many refugee children, family life was not a steady point. Traumatic experiences accompanied memories of the past. The children also had to deal with the obvious tensions between family life at home (involving cultural practices of the country of origin) and their new life outside the home (encountering the new culture and youth culture; Christopoulou and de Leeuw, 2004).

The clubs met weekly after school hours during the course of a year, with some extra full days during school holidays. They made videos and exchanged them on the internet. In each country, the researchers and media educators employed by the project collaborated with youth workers and teachers already working with the children. The clubs became social centres as well as a place to learn about and make media. Using the internet, a communications network was established via a website and an intranet between the six media clubs to facilitate the sharing of children's media productions and to generate dialogues between them. It was also possible to supply verbal comments in a specially designed chatroom in connection with presentation of the videos.

\section{Data collection}

The research approach was ethnographic fieldwork. This was an in-depth study of small groups of children or young people, their social relationships and experiences of schools and communities, the process of making media and the media productions themselves. Thus, what the children said, how they acted and how they negotiated and challenged their places in 
relation to each other and within social institutions were all important. Different types of data were gathered during the course of the site-specific case studies. Fieldwork was conducted for one year, and in some countries even longer. All in all, there are data on 60-80 children (some children left the clubs during the fieldwork period or new children came in), but a core group of $8-10$ children in each club participated during the whole fieldwork period. The data included:

- detailed field notes based on participant observation of groups at work; video and audio tapes of discussions and practical activities;

- pre- and post-production interviews and ongoing briefing interviews with participants;

- interviews with facilitators or tutors;

- feedback from local audiences (for example, parents and peers); and

- the children's productions themselves, in the form of photographs, drawings and digital video productions.

The aim was to be able to present 'thick descriptions' (Geertz, 1973) of the activities and processes going on within the clubs.

\section{Social context of the project}

The context in which the project took place was of crucial importance for the resulting media productions. The social context of the club was also the base for the ethnographic fieldwork. The researchers acted as extra resources during the sessions, but their role was primarily to observe and take notes on relevant processes and actions going on in the club. The setting was an arena for rich and intense discourses between children, educators and researchers. It also provided a good opportunity to study children's negotiations and development of stories; their editing as well as their knowledge of audiences. In fact, the project can be classified as Alasuutari's (1999) 'third generation' reception type of study, exemplified by Tulloch (1999), who suggests that we need ethnography of production because within the production space and the discourses there, the implied audience is imagined and created. By observing the production process, we also learn about reception.

Following Tulloch, we attempted to understand holistically the sociocultural processes (Tulloch, 1999), patterns and practices of groups of children in a comparatively informal setting (as opposed to school). Tulloch's concept of 'understanding' includes an emphasis on subjective reflexivity. 'Process' includes an emphasis on the competing rhetoric and intertextuality that define social situations; and 'holistic' emphasizes the understanding of everyday interaction within its broader sociological context of 'discourses within which the media are discussed' (1999: 153). Furthermore, Tulloch seeks to describe the rhetoric, schemas and mythologies by which we make our actions meaningful. 
The media educator had an important function and it was obvious from the outset that the teaching style of the educator varied across clubs, from a person with a more laid-back attitude, ready to step in when required, to a more authoritarian attitude and intervening approach. Such differences were related to a mixture of factors such as personality, experience, educational background and pedagogical philosophy. We also found that the teacher's attitude was partly connected to the students' maturity and age. Some clubs had slightly younger children, for example, in Greece and the Netherlands, which required a more supportive and intervening approach on the part of the teacher.

\section{Media production process}

One important aim of the CHICAM project was to create a space in which the children felt free and comfortable to express and develop their migration experiences using digital media technology. The role of the educator and researcher was to listen and encourage children's initiatives. However, one cannot expect that an arrangement such as the CHICAM club would immediately invite the children to openly discuss and elaborate on sensitive and sometimes traumatic experiences. Thus, themes were defined which the clubs should work on and which reflected key issues in children's lives, as follows:

- peers - in order to capture issues of friendship, for example, inclusion and exclusion;

- family - in order to capture the children's perceptions of 'home' and belonging, related to both the homeland and the host country; and

- school - in order to capture the children's perceptions of the school as a space for learning and play (this theme is discussed more specifically elsewhere, for example, Passani and Rydin, 2004).

In general, the different themes appeared to be difficult to separate, as the children often focused on mixed themes such as films about friendship in school, exclusion and inclusion in school, or friendship in a family context. As stated at the beginning of this article, it will focus on the themes related to narratives about peers and family, often with an emphasis on establishing new relations or on ties and relations with the past. It was observed that, during the course of club work, the children became increasingly interested in expressing themselves freely. More spontaneous and personal expressions were produced by hand. In the beginning, technology was a great obstacle, but eventually the children developed less formal forms, such as inbetween occasions when there was no structured education at all. For example, the children in the Netherlands could enter a room where they could be by themselves, without adult surveillance. In Sweden, the children could use the school corridor or they could go outside with the cameras. 


\section{Discussion}

\section{Fictions}

The children were assigned to produce a series of fictions portraying their reflections on 'peer relations'. The outcomes of this task had some common denominators, but there were also great differences between the clubs. The preparation process can be outlined as follows: the researchers and educators had the common idea that the production should deal with the topic of exclusion and inclusion. In order to make sense of this task, the children were asked to think about 'friendship'. All the clubs initiated the task with a brainstorming session where the children could discuss what friendship really meant to them. The topic also stimulated extensive group dynamics and gave rise to a great deal of arguing, negotiations, proposals and ideas. Ideas were refused or changed until the group attained some kind of agreement on the story to be told. Usually, the story was then drawn and written on a storyboard, in more or less detail. In some clubs, the children were divided into smaller groups to make the task more manageable.

There were some striking similarities with regard to choice of topics. The children tended to cultivate the myth of friendship, i.e. that a friend is a person you can trust and who helps you when you are in trouble. The troubles were generally concrete and 'physical', for example, the character has lost something important and the friend helps them to find this object (for example, something valuable such as a purse, or a comforting object such as a teddy bear). Thus, the children were thinking of universal, fundamental topics. They rarely thought about their particular migrant situation. The narrative style was straightforward and did not seem to involve any conceptualization of the audience. It seemed as though they relied on known genres and conventions adopted from film or television.

However, one Greek production, 'Ali and Vladimir', was an exception to this rule. In the Greek club, the brainstorming session led to a discussion about loneliness, nostalgia, unemployment and insecurity in the new country. One reason why this theme raised such lively discussion was that the children perceived an insecure and vulnerable situation. Unlike the other clubs, the Greek club was located in a refugee centre:

Yet, what stands out here, is the openness of the children in referring to past friendships: friends they lost, friends they missed, friends they parted from, friends they re-encountered, friends they made on the journey, friends they 'dreamed of'. The split routes of migration come up like words in a game: Turkey, Afghanistan, Greece, Germany, and Belgium. They referred to their country of origin and also to their insecurities and loneliness in the new country. They referred to the feeling of exclusion and the difficulties of integration, but also to the support they experienced on crucial moments. It seems that the latter is highly valued in their mind. Also there were references to people that they met on critical points in their life and whom they often called friends: i.e. people on the boat on the way here, people on a refugee camp. (Christopoulou and Rydin, 2004) 
The film begins with the silent steps of a refugee child who misses his friends in his country of origin, and who suffers from homesickness and isolation in the new country of residence where he feels he does not 'belong'. The experience is accentuated by the fact that he cannot easily enter the peer networks of children of his age. At a critical moment, he meets and befriends another child who also happens to be a migrant. The common past experience as well as the similar problems that they both face in the 'new' country bind them together. Their friendship is marked by the fact that one boy has to leave again, due to family problems stemming from the uncertainty and vulnerability of their immigration status (his father has lost his job). The climax is the farewell scene between the two children and the exchange of mementos symbolic of their friendship (Christopoulou and Rydin, 2004).

In the case of 'Ali and Vladimir', the planning of scenes followed a schedule set up by the educator and researcher. It extended over a number of weeks in different settings, outdoors and indoors, with a number of actors (Christopoulou, 2004). The film uses symbolic language to some extent, such as a boy crossing the street when the light is red, symbolizing that he is in a bad mood and does not care about what happens to him. The red traffic light is shown in close-up. Another scene marking the boy's mood shows his gaze turned towards a children's playground with noisy children playing; this is used to emphasize his loneliness. The children making this production were also demonstrating their knowledge of clichés and stereotypes, as they were anxious that the people involved should have an immigrant look; for example, they showed an immigrant mother cleaning the street. The setting should look 'poor', the children thought. This production was carried out with the guidance of the media educator, who was also a professional media artist. The high quality of the film suggests that the editing took some time. The film is based on children's own personal experiences, their collective memory of migration experiences, and developed further to a story which could be real. This story is then embellished using conventional dramaturgical devices, codes, conventions and storytelling, also partly inspired by the children themselves.

\section{Real-life stories in documentary format}

It was discovered that representing personal stories was very difficult. Fiction does not seem to be the most appropriate format for dealing with authentic events that the children may have experienced in their lives. It turned out that a mainstream reality show could be a source of inspiration for representing personal stories. One example was a video inspired by the reality series Big Brother, made by children in the Swedish club. A small group of children went to an adjacent room with a camera and pretended that they were filming Big Brother. The outcome of the production was initially private, and the children were reluctant to show it. But they 
eventually showed it to the media educators and the researcher, thanks to the confidence which had been built up during the long period of fieldwork. The discussion during the Big Brother confession happened to shed light on the issue of friendship. It was about love between immigrant girls and Swedish boys, whether the boy should be 'blond' or 'dark', as well as about 'trust'. Being 'blond' is a commonly associated with Swedish people, and here a kind of ambivalence was expressed. The two girls making the confession seemed to like both 'blond' and 'dark' boys, but they finally concluded that if you are dark yourself, you prefer a dark person and that such a person is to be trusted. They did not talk about trust when commenting on Swedish boys. Another story confession dealt with a close friendship between two girls and an incident challenging their friendship. In both films, the children are negotiating their identities as Albanians in the new country. They express their strong emotional connection to their Albanian origin and, at the same time, they express a wish to be more involved in Swedish society. Both examples illustrate negotiations of identity positions in talk. In other words, the children perform their hybrid identity in the dialogues and talk (Tate, 2005).

This example also demonstrates how the children accommodated the reality format to fit their own interests without imagining a wider audience, except for their private friends in the confession room (the cameraman, a boy, and another girl). We believe that portraying personal experiences in this way may capture emotional aspects and feelings in a more authentic way than an assigned task. The confession becomes a social construction of the children's reality, which is close to real emotional moments in their lives. Here we are given access to the 'back stage' (Goffman, 1969[1959]), implying that the picture of friendship is more complex and ambivalent than in a fiction. It portrays what Vansina (1985), in his study of oral culture, refers to as 'double portraits' and draws a distinction between private and public image. According to his analysis, the public image (the 'front stage' in Goffman's terminology) is formed according to structure and order (for example, a conventional fiction story), whereas the private image contains contradictory memories and reveals signs of fear and doubt. Having 'visualized stock material of personal experiences', the children may then produce a fiction based upon these visualized experiences. The point is that the children move beyond the stereotypical portrayals that are common when they make 'simulations' (Buckingham, 2003). Instead, they preserve the complexities of real life and start the production process from within a different frame than they would with a 'pretend' story.

In cases where personal stories evolved around family life, the children concentrated on the here and now, as well as on the future, rather than the past, which was much more difficult for them. This example, 'Hana's Family', illustrates a girl's personal story of family life in her new country, Sweden. In brief, this project had the following ingredients. 
Hana borrowed a camera and brought it to her home; she was free to use it as she liked without supervision from the media educator. She shot the film and took the role of narrator most of the time. She also chose all the scenes and episodes, and finally edited the film by herself, without guidance. The result was a film inspired by celebrity home reportages, thus making intertextual references to familiar genres. Hana's film is a narration about happy moments in family life, as she preferred to present a picture of a good life in her new country. At first, she focuses on her private sphere, by presenting her own bedroom, scanning all the precious objects there: pictures on the walls, her bed with all her soft toys, and other souvenirs. She then shifts perspective towards the sphere of family life and brings the camera outdoors, presenting a walk to her brother's house together with her sister and mother (Hana's family, no doubt, includes the brother's family). She dwells upon her brother's infant son, who becomes the final picture in the film. When editing the film, she freezes pictures into stills, which indicates her emphasis on important people in her life. These motifs are her mother, her sister and the little baby, particularly when they laugh and smile. What stands out is Hana's wish to solidly engrave the image of happiness within the family. As the youngest child in a big family, she had experienced older siblings moving out of the house and the family becoming reduced and perhaps less integrated. This image of a 'happy family' must be considered in relation to disruptions and their escape from Kosovo. Even in other projects, Hana focused on cultivating the idea of a happy family, an idealized representation of 'home'.

\section{Performances}

Performing resulted in a great deal of fun. Most children liked to perform in front of the camera, communicating movements, gestures and suchlike. This may not be very different from how they 'use' performances seen on TV in their own life (such as copying the movements of Britney Spears, Shakira and breakdancing acts). This links up with the notion that pop music is the dominant form of youth entertainment represented by and on MTV and other pop music channels. These channels, through their performing stars, express lifestyles which offer platforms for identity construction for young people (Frith, 1993). In the Dutch club, a spontaneous idea surfaced to visualize different ways of greeting, the very beginning of communication and forming relations with other people. The different styles of saying 'hello' turned out to be based on a combination of spontaneous expressions and knowledge about structure, i.e. cultural codes or schemas for greeting. The girls worked separately from the boys, and their different styles of greeting (from different cultures) were also gender specific. The boys mainly made tough-guy gestures derived from rap, whereas the girls made elegant gestures and little dances. The girls added their own favourite pop music to guide the images, making their own straightforward little music video. 
Another example here is rap, a global language which could possibly encourage cohesion within the club and across club boundaries. For boys, this is an important way of expressing themselves, as is breakdancing, one of the other popular leisure activities in the clubs. Both are very much part of a (male) youth culture, and this is exactly what was communicated among the boys: this is our world and we understand this world well. Only the boys made rap videos and mainly boys responded to the rap videos made in other clubs (de Leeuw, 2004). The rap case illustrates the close relationship between pop music and identity that Frith (1996) pointed out. The direct experiences of the body, time and sociability that music offers enable young people to place themselves in imaginative cultural identities (Frith, 1996). In a material way, the boys looked for a common cultural ground and placed themselves in a specific social and cultural group. Their choice of music was also related to their status as boys at the beginning of puberty. They were attracted by the macho image of the male black person conveyed in rap music. For immigrant boys, the situation has become more complex, as their male identity has become unstable in the context of modern society. Their insecurity is compensated by a tough attitude towards this society (De Block and Rydin, 2006; Sernhede, 2002).

Performing is representing the self; it helps the individual to become more secure and offers basic conditions for eventually developing personal empowerment. The camera was literally a mediator between the children and the social world onto which they had projected an idealized portrait of themselves. Performing scenes, rap and animation, as will be discussed below, turned out to be most helpful formats, allowing the children to articulate both teenage style and individual (subcultural) style.

\section{The animation format}

In creating animated narratives, the children's fantasy and their ability to think visually were stimulated. It also enabled discussions of personal experiences without being too confrontational. As the children could create their own setting, characters and objects with drawings, clay and pieces of candy, their choices reflected the way that they thought about visual imagery. Some children definitively chose to work in a naturalistic mode, while others much preferred fantasy and non-realism. There was no relation to the content of the stories they visualized at all. Some stories were taken directly from the children's social environment, such as a drawn animation about a beggar from Greece, while others came up with funny stories trying to capture the essential creative potential of animation. These stories were, for example, about: a loving couple and a dog who disturbs their relationship by urinating on the heart and defecating on the flowers (both the animated heart and flowers meant to visualize love); a bank raid in a German city (identifiable German police cars); a vacuum 
cleaner sucking up wet laundry; a little man whose trousers split; and football (starring 'David Beckham').

However, animation also proved its value in addressing more personal experiences, such as taking responsibility at home. In 'Kwik, Kwek and Kwak', made by a boy from Congo in the Dutch club using liquorice allsorts, he tells the story of how he has to look after his three younger brothers and sisters. They are very naughty, and sometimes they play war games using small wooden cubes. If he watches television, they throw the cubes at his head, which makes him very angry. Obviously, the boy does not mind being responsible, as long as the three young ones behave well. He is not the eldest of the family; there is an elder brother who does not seem to live at home, and there is his elder sister who has taken over many more responsibilities from their mother than she has been asked to do, and who mainly does the translations for their mother, who hardly speaks any Dutch but instead French and a Congolese 'family language'. His animation also reveals one of his favourite activities at home: watching music video clips. In his animation, he designed five frames with pictures of his family on the wall: first his older sister, then himself, then the three small children. By literally drawing family portraits, he confirms the family ties. He also represents himself as an average teenage boy who watches a music video channel and enjoys global youth culture. At the same time, however, he does not hide his African background and uses African symbols in his animation drawings. The boy constructs himself as a caretaker or caregiver as well as articulating emotional connectivity in his portrayal of family ties. Here the crossroads of different cultures is linked to family life as it manifests itself within the private space of the house.

These kinds of references to the home culture, the culture of origin, can also be found in a German production 'At the Beach', in which a Tunisian boy presents a story taking place in his homeland, at the beach. First, he introduces the sunny environment of an African country in a few shots (very naturalistic). Within this setting a little story develops about three clay boys playing football, one of whom is hit by the others and saved by another boy with whom he starts playing again. The boy had taken the pictures himself in Tunisia and suggests that the sand comes from there. Although the sand was created using a beige-coloured bath towel, in his explication on the intranet, he attributes to it a Tunisian and hence 'authentic' origin: 'I brought the sand from TUNISIA.' It seems as though he was so proud of the reality effect he had produced in his audience that he did not want to admit to using a trick, and was prepared to use false information in his reply to maintain the impression he had created (Holzwarth and Maurer, 2004).

Most conspicuous here are the 'accents' that the children put into their productions, referring to their personal diasporic history (Naficy, 2001). In his book on exilic and diasporic filmmaking, Naficy (2001) discusses 
how filmmakers living in exile or diaspora make 'accented' films that reflect ethnic consciousness and distinctiveness. We are well aware that Naficy discusses professional yet non-mainstream filmmaking, although the examples discussed here do reflect a need observed among the children for putting 'accents' into their productions, a need for a certain distinctiveness in the sense of (ethnic) origin.

Also, animation offered the children the possibility of reworking refugee experiences that were difficult to talk about openly. In a drawn animation movie called 'The Asylum Seekers' Centre', a Syrian girl gives us a glimpse of family life in a situation of homelessness, expressing the uncertainty of being and becoming. The drawings are filmed with the camera and her story is recorded separately and dubbed later. First, she introduces the centre and then herself and a friend playing. In only a few shots, she presents a range of events that may occur in a refugee's life in the centre and which actually did occur in her life: someone is dying, the family is trying to survive in a very small trailer, the fear of being pulled out of the trailer by the police in order to be expelled, a possible happy ending: a house of one's own. Through the animation movie, she was able to rework her own experiences and worries. For her, the experience of living in an asylum-seekers' centre was still very important and crucial to how she perceived the world. Again, this particular animation illustrates Naficy's argument about accented filmmaking. The productions discussed here are, as he puts it, personal and unique, 'because they are both authorial and autobiographical' (Naficy, 2001: 34).

\section{Photo video collages for conceptualizing the past}

During the research, the children and their families' need to somehow relate to the past and to keep the origins alive in their new space gradually emerged. This was both a delicate and a difficult topic, as it brought to the fore how the families had suffered from disruption and discontinuity in their lives. As a consequence, this topic was not raised in all media clubs. However, children in several clubs confirmed the importance of photographs. Photographs seem to be the most concrete proof of a family life 'there', and help to keep memories alive. A few examples may illustrate the possibilities of pictures in terms of self-expression and self-representation (de Leeuw, 2005).

In the UK club, it was clear that, over the year, family stories changed or rather stories were told differently according to context. Sahra from Somalia was very willing to speak about her family and their lives, but it became clear that what she told was not the present reality, but stories now past, stories of happier times. She told these stories to maintain an image and to help her through the present bad times. In a video made at the very beginning of the club, she showed photos of her family (particularly of her father, who had died) and talked about Somalia. Her film is very much based in the past. 
In the Dutch club, each of the children made a 'Family Video Show' based upon existing family pictures that they selected at home and took to the club. First, the children were asked to tell each other about the pictures, then to make a selection, to shoot this selection with a digital video camera, and then to write a text to go with it which was dubbed later, spoken by each child. In different ways, pictures and how families deal with them are especially illustrative of the extent to which families in diaspora remain connected to the country of origin, which represents the home that the families have lost. One boy brought many pictures showing his home country, Somalia. They represent life as it is taking place 'there', showing his grandfather's land, the camels he owns, the drinking place, the beautiful light, the colour of the sand. Longing notions of African life are inscribed and reinforced by the story that the boy told with the pictures, a story that he in turn had heard from his own father. Traditions of oral storytelling, through which the family keeps its own culture and history alive, were reproduced in the boy's family video collage. Another boy had no autobiographical memories of his homeland, the Democratic Republic of Congo. In the club, he made a family video using existing pictures from the family and a 'new story' along with those he told by himself. We observed how he invented stories that mixed stories told within his family and stories he might have heard or read, for example, on TV or in a newspaper. He was obviously involved in creating a family history for himself in order to develop his identity in the present, and media helped him to fulfil his ambition. This combination of pictures and commentary enabled him to tell his family history as a continuous story in which the 'there' and 'here' were linked. What we saw happening was a process of active construction of personal history through the use of what Hoskins (2001) calls 'memory devices', pointing to photo albums, home videos and suchlike. The medium at least partly becomes memory.

Another example may illustrate how the medium indeed literally mediates between the past and the present. Ibish was the only member of the Swedish club who showed family photos from Kosovo. On one occasion after a couple of months, he brought a set of pictures that had been well thumbed. They were taken during a trip to Kosovo when the whole family visited the village in which they used to live. Several pictures focused on the remains of their house, which was burnt down during the civil war. It was originally a farm surrounded by buildings. Then there were pictures showing his father building a new house. One picture featured a small cottage in the woods. It looked new. It was a cottage they received as aid after the war and were supposed to live in during restoration of the farm. Ibish said that the house was of poor quality and that the roof leaked. Other pictures were very beautiful, of a lake or parts of a bay. Although the village was not on a map, Ibish pointed out the spot. He also noticed that the text on the map was in Serbo-Croatian. Ibish had returned to his 
memories from the village more than once. He also made a drawing of the village and the graveyard where his grandfather is buried. A next step would have been for Ibish to rework the pictures into a narrative linking the different disrupted moments in his family history.

We have noticed how specific media formats helped the children to work with an aspect of their lives as intimate as the family. The photo video collage enabled them to work with personal material addressing the family history (pictures, memories) and to process these into a media form. These stories obviously present memories of their lost home and homeland, a part of their history and their ethnic identity.

\section{Conclusion}

In their self-expressive media productions, the children spoke plainly about themselves, and in so doing they actually entered the process of identity construction, if in a playful way. Making media turned out to be a useful expressive means capable of constructing notions of both individual (the different roles one plays at different moments) and collective (emphasizing common cultural values and standards, such as in terms of religion, nationality or ethnicity) identities. It was noticed how the children, in their media productions, expressed cultural identities of the complexity described by Barker (1997). Their media productions reflected the notion of difference and equality and can be categorized along the different cultural axes that Barker describes in terms of two mutually exclusive categories. They might, however, become integrated in the discursive competence that individuals develop in constructing their identities (Baumann, 1999). An 'introverted' (inward looking) approach can be found in media products where the children kept two identities separated, such as German and Tunisian, in the animation, and emphasized being Tunisian. 'Trans-local' (outward looking) refers to a more hybrid construction of identity in which different sources for identity construction merge into a new one, such as in the animation of the Congolese boy who does not choose either, but presents a Dutch Congolese identity (Barker, 1997). Plurality and hybridity of identity were 'accented' in the children's media productions through references to their homeland, religion, history and descent. As Naficy (2001) argues, accent is one of the most intimate and powerful markers of group identity and solidarity, as well as of individual difference and personality. It is through these accents in particular that the children voiced a personal experience and perception of themselves.

As the children learned to better understand the conventions and possible effects of the camera, they acquired the skills to present themselves in front of the camera and visualize their experiences. Besides the experience of making media, viewing together also enhanced their sensibility for 
media aesthetics. Children discovered that media, especially TV, do have a creative potential and are not only to be passively consumed. Buckingham (2003) claims that 'media production provides a space in which students can explore their pleasures and emotional investments in the media, in a way that is much more subjective and "playful" than is the case with critical analysis' (2003: 162). In addition, pleasure does permeate the children's productions, despite some of their vulnerable lives as refugees. They seemed to be reluctant to take things seriously, but the atmosphere was rather informed by joy and play as well as postmodern concepts such as irony and parody. The children constantly tried out different subject positions, showing themselves in different images and positions. Also, at the level of style and expressive communication, creating their own media productions enabled a continuous process of identity construction. It was obvious that mainstream entertainment programmes were in the children's minds as sources of inspiration during production work. This tendency was more pronounced when children were given free rein to express themselves. Even though the selected format or genre was sometimes conventional, the narratives or stories told always originated from personal experiences.

As to the 'action' part of the project, which was directed at educational policy for the future, it seemed as if creative media production provided a media space that could enable development of personal empowerment. Working with the media seemed to stimulate the process of selfrepresentation. The productions that the children made (both about their past and present lives) became new artefacts for them, confirming their identity and helping them to fantasize about the future. The media club also provided a productive space, particularly for those children who had limited access to 'free spaces' at home, at school or in society.

\section{Acknowledgement}

The Children in Communication about Migration project was funded by the European Commission, Community Research.

\section{References}

Alasuutari, P. (ed.) (1999) Rethinking the Media Audience. London: Sage.

Barker, C. (1997) Global Television. An Introduction. Oxford: Blackwell.

Baumann, G. (1999) The Multicultural Riddle. Rethinking National, Ethnic and Religious Cultures. London: Routledge.

Braziel, J.E. and A. Mannur (eds) (2005) Theorizing Diaspora. A Reader.

Oxford: Blackwell.

Buckingham, D. (2003) Media Education: Literacy, Learning and

Contemporary Culture. Cambridge: Polity Press.

Christopoulou, N. (2004) 'Intercultural Communication', working report (WP 6), CHICAM, European Commission, Community Research. Athens: 
Christopoulou, N. and S. de Leeuw (eds) (2004) 'Home Is Where the Heart Is.

Family Relations of Migrant Children in Media Clubs in Six European Countries', European Commission, Community Research deliverables 11 and 12, February. [Available at: http://www.chicam.org]

Christopoulou, N. and I. Rydin (eds) (2004) 'Children's Social Relations in Peer Groups: Inclusion, Exclusion and Friendships', European Commission, Community Research deliverables 7 and 8, February. [Available at: http://www.chicam.org]

Dayan, D. (1999) 'Media and Diasporas', in J. Gripsrud (ed.) Television and Common Knowledge, pp. 18-33. London: Routledge.

De Block, L. and I. Rydin (2006) 'Digital Rapping in Media Productions. Intercultural Communication through Youth Culture', in D. Buckingham and R. Willett (eds) Digital Generations. Children, Young People and New Media, pp. 295-312. New York: Lawrence Erlbaum.

De Block, L., D. Buckingham, P. Holzwarth and H. Niesyto (eds) (2004)

'Visions across Cultures: Migrant Children Using Visual Images to

Communicate', European Commission, Community Research deliverables 14 and 15, May. [Available at: http://www.chicam.org]

de Leeuw, S. (2004) 'Intercultural Communication-Visual Language: The Netherlands', working report (WP 6), CHICAM, European Commission. Utrecht: OGC.

de Leeuw, S. (2005) 'Migrant Children Mediating Family Relations', in P. Pisters and W. Staat (eds) Shooting the Family. Transnational Media and Intercultural Values, pp. 41-55. Amsterdam: Amsterdam University Press. Frith, S. (1993) 'Youth/Music/Television', in S. Frith, A. Goodwin and

L. Grossberg (eds) Sound and Vision. The Music Video Reader, pp. 67-83. London: Routledge.

Frith, S. (1996) 'Music and Identity', in S. Hall and P. du Gay (eds) Questions of Cultural Identity, pp. 108-27. London: Sage.

Geertz, C. (1973) The Interpretation of Cultures. New York: Basic Books.

Giddens, A. (1991) Modernity and Self-Identity. Self and Society in Late

Modern Age. Cambridge: Polity Press.

Gillespie, M. (2000[1995]) Television, Ethnicity and Cultural Change. London: Routledge.

Goffman, E. (1969[1959]) The Presentation of Self in Everyday Life. London: Allen Lane.

Hall, S. (1996a) 'New Ethnicities', in D. Morley and K.H. Chen (eds) Stuart Hall: Critical Dialogues in Cultural Studies, pp. 441-9. London: Routledge. Hall, S. (1996b) 'Introduction', in S. Hall and P. du Gay (eds) Questions of Cultural Identity, pp. 1-17. London: Sage.

Holzwarth, P. and B. Maurer (2004) 'Intercultural Communication - Visual Language: Germany', working report (WP 6), CHICAM, European

Commission. Ludwigsburg: University of Ludwigsburg.

Hoskins, A. (2001) 'New Memory: Mediating History', Historical Journal of Film, Radio and Television 21(4): 333-46.

Huntemann, N. and M. Morgan (2001) 'Mass Media and Identity Development', in D.G. Singer and J.L. Singer (eds) Handbook of Children and the Media, pp. 309-20. Thousand Oaks, CA: Sage. 
Morley, D. and K. Robins (1995) Spaces of Identity. Global Media, Electronic

Landscapes and Cultural Boundaries. London: Routledge.

Naficy, H. (2001) An Accented Cinema. Exilic and Diasporic Filmmaking.

Princeton, NJ: Princeton University Press.

Passani, A. and I. Rydin (eds) (2004) 'School as an Arena for Education, Integration and Socialization', European Commission, Community Research deliverables 9 and 10, February. [Available at: http://www.chicam.org]

Sernhede, O. (2002) Alienation Is My Nation. Hiphop och unga mäns utanförskap i det nya Sverige [Alienation Is My Nation. Hiphop and the Marginalisation of Young Immigrant Men in the New Sweden]. Stockholm: Ordfronts förlag.

Tate, S. A. (2005) Black Skins, Black Masks. Hybridity, Dialogism, Performativity. London: Ashgate.

Tulloch, J. (1999) 'The Implied Audience in Soap Opera Production Everyday Rhetorical Strategies among Television Professionals', in P. Alasuutari (ed.) Rethinking the Media Audience, pp.151-78. London: Sage. Vansina, J. (1985) Oral Tradition as History. London: Currey.

\section{Biographical notes}

Sonja de Leeuw is Professor of Dutch Television Culture in an International Context at the University of Utrecht. She is the author of Television Drama, Stage for Identity (Cramwinckel, 1995; in Dutch). She publishes on television culture, historical representation, media and diaspora, and media and youth culture. She is coordinator of a European Union-funded project, 'Video Active' (www.videoactive.eu). ADDREs s: Media and Cultural Studies, Faculty of Humanities, Utrecht University, Kromme Nieuwegracht 29, 3512 HD Utrecht, Netherlands. [email: sonja.deleeuw@let.uu.nl]

Ingegerd Rydin is Professor in Media and Communication Studies at Halmstad University. She is the editor of Media Fascinations: Perspectives on Young People's Meaning Making (Nordicom, 2003). She publishes on media history and media reception with a focus on children and young people, and media and diasporic cultures. A DDRESS: Media and Communication Studies, School of Social and Health Sciences, Halmstad University, PO Box 823, SE-301 18 Halmstad, Sweden. [email: ingegerd.rydin@hos.hh.se] 